\title{
Solidarity in Europe-European Solidarity: An Introduction
}

\author{
Christian Labusen and Maria Grasso
}

\section{INTRODUCTION}

Solidarity has received heightened attention in public debates during the last decade, because the various crises affecting the European Union have put the idea of European solidarity under stress. This is true in regard to the economic and financial crisis that has severely hit many European countries since 2008. Even though the European Union has developed a number of policy measures (e.g., the 'European Financial Stability Facility', the 'European Stability Mechanism', and the 'Stability and Growth Pact') which have opened the door to financial assistance, the European Union remained committed to a bail-out policy package that discarded a communitarization of debts and put the main burden on countries threatened with bankruptcy by imposing strict austerity measures. As a reaction, most commentators converged upon the conviction that international solidarity was dead (see Habermas 2017; Balibar 2010). A similar conclusion was drawn in regard to the issues emerging in reaction to the

\section{Lahusen $(\bowtie)$}

Department of Social Sciences, University of Siegen, Siegen, Germany

M. Grasso

Department of Politics, University of Sheffield, London, UK

(C) The Author(s) 2018

C. Lahusen, M. Grasso (eds.), Solidarity in Europe,

Palgrave Studies in European Political Sociology,

https://doi.org/10.1007/978-3-319-73335-7_1 
increased inflow of refugees from Syria and other regions affected by wars in 2015 and the inability of the EU institutions and its member states to agree on a coordinated asylum policy and mechanisms of admission and integration. Consensus could only be reached in regard to the external dimension (e.g., frontier controls, fight against human trafficking), leaving the issue of fair burden sharing through national quotas and relocation programs unsolved.

The success of populist parties in many European countries (e.g., France, the United Kingdom, Denmark, Italy, Spain), the Brexit vote, and the mobilization of Eurosceptic and xenophobic protests across Europe has raised further concerns that European solidarity might be at risk in a more fundamental and all-encompassing manner. In times of crisis, we might not only be witnessing the erosion of cooperation between member state governments but also the corrosion of social cohesion at the level of the European citizenry, thus threatening the social foundations on which EU institutions and policies are built. Does the crisis of European integration translate into a crisis of European solidarity, and, if so, what are the manifestations at the level of individual citizens? Is European solidarity really on the retreat within the European citizenry? How strongly is solidarity rooted at the individual level, both in terms of attitudes and practices? And which driving factors and mechanisms tend to contribute to the reproduction and/or corrosion of solidarity in times of crisis?

We are urgently in need of sound empirical evidence in order to answer these questions. Public debates and contentions continue to return to this issue, but we so far have very little empirical evidence on which to draw in order to inform this debate. Listening to these public debates, it seems as though pessimists are on the forefront. According to these views, the various crises affecting the European Union are putting European solidarity under strain. In times of economic growth and optimistic economic outlook, it should be easier to profess cooperation and help, while solidarity seems to be much more difficult to sustain in times of recession and scarcity. This is particularly true given that populist and xenophobic political entrepreneurs can draw on the exacerbation of citizens' fear and grievances and that the crisis overlaps with a long history of ineffective policies in key domains, such as poverty and unemployment, immigration, and asylum. Under these circumstances, political debates seem to be marked increasingly by antagonism, conflict, and mistrust between governments and citizens, to the detriment of social cohesion and solidarity. In spite of this pessimistic outlook, there is, however, some room for optimism left. 
It remains to be said that 60 years of European integration have gradually established feelings of belongingness to the European community, enabled shared identification with European institutions, as well as European and cosmopolitan identities (Delanty and Rumford 2005; Beck and Grande 2007). Moreover, European integration has furthered cross-national experiences and contacts among citizens, as well as transnational trust between European peoples (Delhey 2007). Finally, public opinion polls show that, in the midst of the European crisis, a majority of respondents still agree that it is desirable to give financial help to other countries in the name of European solidarity between member states (see Eurobarometer 2011; Lengfeld et al. 2012). The same is true for the readiness of European citizens to support a fair burden sharing in regard to refugees, if this is necessary to uphold the achievements of the European Union, such as Schengen (de Vries and Hoffmann 2016).

This book tries to systematically shed light into this debate by presenting findings of a population survey among citizens of eight European countries, namely, Denmark, France, Germany, Greece, Italy, Poland, Switzerland, and the United Kingdom. The survey was conducted in the context of an EU-funded research project devoted to the study of European solidarity ('European Paths to Transnational Solidarity in Times of Crisis'-TransSOL). TransSOL aimed to increase knowledge about solidarity within the general population, organized civil society, and the media. The consortium consisted of members from the following institutions: the University of Siegen (Germany), the Université de Genève (Switzerland), the Fondation Nationale des Sciences Politiques (France), the Glasgow Caledonian University (United Kingdom), the University Panepistimio Kritis (Greece), the University of Florence (Italy), the University of Warsaw (Poland), the University of Copenhagen (Denmark), the University of Sheffield (United Kingdom), and European Alternatives Ltd. (Germany and United Kingdom). The project received funding under the Horizon 2020 program (Grant Agreement No: 649435). The survey was subcontracted to a specialized polling company (Info GmbH).

The aim of the survey was to build a comparative dataset that would allow us to measure levels of solidarity among the member states' citizenry and to help identify those social and political factors that might promote or inhibit solidarity both within the member states and across their borders. This study was demanding, given the fact that solidarity is a complex phenomenon that requires careful reflection, definition, and 
operationalization and that a nuanced conceptualization is particularly necessary when addressing the notion of European solidarity. Hence, before we move to the presentation of findings for each of the eight countries, it is thus necessary to engage in a conceptual discussion of European solidarity. For this purpose, we will present available evidence on the topic and systematize this knowledge within a conceptual framework apt to guide our empirical analyses.

\section{Contributing Knowledge to an Established Field of Research: Concepts, Measurements, AND Assumptions}

Solidarity is one of the key phenomena studied in the social sciences. Research in sociology, economics, political sciences, and psychology, among others, has been inquiring for many decades into the forms and conditions of social integration and cohesion in order to better understand the social foundations of societies (Durkheim 1893/1997; Marshall 1950; Parsons 1966). However, the focus has been on national societies, which means that our knowledge about the transnational dimension of solidarity, and in particular about European solidarity, is rather limited. The limitations are even more serious once we move to the individual level and inquire into the attitudes and practices of the European citizenry with reference to European solidarity. How strongly is the idea of European solidarity shared by citizens throughout Europe, and to what extent are they engaged in solidarity-related activities? Is solidarity limited to specific communities or target groups, or do we detect also a universalist or cosmopolitan philanthropy dimension? What can we say about the social traits, beliefs, and convictions of people engaged in solidarity activities? And which are the factors inhibiting solidarity dispositions and practices?

In order to answer these questions, we need to develop a clearer understanding of what we mean by (European) solidarity. In this regard, we propose to follow a much quoted definition by Stjerno who defines solidarity as the preparedness to share one's own resources with others, be that directly by donating money or time in support of others or indirectly by supporting the state to reallocate and redistribute some of the funds gathered through taxes or contributions (e.g., Stjerno 2012: 2). Under this wide conceptual umbrella, research has tended to focus on a series of different expressions of solidarity. Studies have been interested in 
interpersonal 'social' solidarity in informal groups or networks (e.g., Hechter 1987; Markovsky and Lawler 1994; Komter 2005). They have addressed volunteering, membership and support of voluntary associations, civil society organizations, and social movements (Curtis et al. 2001; Putnam et al. 2003; Giugni and Passy 2001). And they have focused on citizens' support of the welfare state and its redistributive policies (e.g., Svallfors 1997; Fong 2001; Amat and Wibbels 2009; Rehm 2009; Rehm et al. 2012).

As useful as this initial definition might be, it does not yet grasp what we consider to be the specific nature of solidarity. In fact, we see the need to distinguish solidarity more clearly from charitable help, care, or humanitarian aid by stressing the group-boundedness and reciprocity of solidarity. According to this conceptualization, solidarity is tied to an (imagined) community or group, whose members are expected to support each other in order to fulfill the mutual rights and obligations associated with group membership (Hunt and Benford 2004). While this conceptualization is admittedly close to the notion of political solidarity (Scholz 2008), as it leans toward a rights-based definition, we argue that it is applicable to social and civic solidarity between individuals, as well. In fact, 'solidarity groups' might be informal cliques, formal organizations, or full-fledged nation-states, but all of them will be based on the idea that membership is tied to the expectations of mutual support, even if these expectations might range from informal to formalized, from voluntary to binding rights and obligations.

This definition has many advantages for the analysis of European solidarity. On the one hand, we need to remember that European solidarity is only one of the many potential group-bound solidarities, besides the region, the nation, or humanity, among many others. On the other hand, we must acknowledge that solidarities are in themselves contentious, because groups maintain both complementary but also competitive relations to each another (Bandy and Smith 2005; Scholz 2008). As an individual, one might feel in solidarity with one's own family, neighborhood, region, and nation, and this feeling might not stand in competition to a sense of solidarity with Europe or humankind in general. In this case, national and European solidarities would be part of a more encompassing, universalist or cosmopolitan notion of solidarity. However, particularly in times of crisis, where citizens are exposed to feelings of scarcity, relative deprivation, and distributional conflicts, (Grasso and Giugni 2016) group solidarities might be either prioritized or sorted out. And this could mean 
that citizens center their solidarity more strongly on their own country and/or specific groups therein, even if they do not discard-in principlethe need to help other Europeans. In this sense, group solidarity acquires a particularistic orientation, because one's own support of others is conditional on the ego-alter's membership in the same group, or at least dependent on its social proximity to it.

These conceptual clarifications highlight that we are dealing with a complex and multifaceted phenomenon that requires prudent operationalization. For this reason, we developed a questionnaire that aimed at measuring individual solidarity along its major components. First, our survey insisted on the need to measure solidarity in its different manifestations. In this regard, we opted to look at attitudes and reported activities at the same time. This differentiation is necessary because it is to be expected that the preparedness to help others does not translate inevitably into factual activities. The latter might disclose prioritized group solidarities much more neatly than the mere readiness to help. We thus opted to include a number of questions in our survey that gather information about the respondents' reported activities of solidarity. These questions presented a wider range of potential activities, ranging from more conventional to more unconventional activities, for example, donating money or time, buying or boycotting products, and active participation in voluntary associations and protest actions (Grasso 2011, 2016).

Second, our conceptual framework insists on the need to measure solidarity in its charitable and political dimensions. Scholarly writing has tended to focus on the (financial) help to the needy, thus privileging the charitable dimension of solidarity. While this aspect is important, it downplays the political and rights-based dimension of solidarity. In fact, people demonstrate solidarity with other persons in struggle or in need when participating in collective actions (e.g., public claims-making, political protests, communication campaigns) that strive to improve the situation of these groups by mobilizing on behalf of their rights and entitlements (Giugni and Passy 2001; Scholz 2008). This political dimension seems of particular importance when dealing with the European Union. In fact, European solidarity is present when people help other European citizens to raise their voice and make it heard, particularly if we are speaking of social groups at the fringes of society that are severely hit by the European crisis (Balme and Chabanet 2008; Lahusen 2013; Baglioni and Giugni 2014; Giugni and Grasso 2018). The survey aimed at measuring both dimensions of solidarity, the charitable and the political. In particular, 
the questions about reported solidarity activities were based on a rightsbased concept of solidarity, because it asked respondents whether they actively supported the rights of various groups by means of the activities listed in the questionnaire. Additionally, we assembled information on political activities and orientations related to solidarity, ranging from protest participation to policy-related issues (e.g., European solidarity measures).

Third, solidarity can be organized at different levels of organization and aggregation, as indicated by previous research. Studies have focused on social solidarity at the micro level, that is, on the interpersonal relations of mutual support between individuals (Hechter 1987; Markovsky and Lawler 1994; Komter 2005). Research has also shown that solidarity is a collective endeavor promoted - at the meso level-by civil society organizations and social movements (Hunt and Benford 2004; Giugni and Passy 2001; Curtis et al. 2001). And, finally, scholars have focused-at the macro level-on welfare state institutions and social policies as an instrument of redistribution committed to the idea of solidarity (Fong 2001; Rehm 2009; Alesina and Giuliano 2011; Rehm et al. 2012). This differentiation provides tools for survey-based research, because it allows measuring individual solidarity as a multiscalar phenomenon. In our survey, for instance, we included questions that asked individuals to report interpersonal practices of support within and beyond their country, to indicate whether they supported civil society organizations or social movement activities and whether they are against or in favor of redistributive policies within their country and between European member states. Even though the focus of this book is primarily on the micro- and meso level, we will see that these various levels of organization and aggregation make a difference. Reported activities of individual solidarity seem to be less diffused, when compared to forms of delegated solidarity, that is, the support of civil society and the welfare state.

Finally, the analysis of solidarity has to take the group-boundedness of solidarity seriously. This means in particular that solidarity might be, more often than not, a particularist commitment. Previous research has consistently shown that solidarity is of little analytic and practical use when conceived of as a generalized disposition or practice. Studies recurrently highlight that solidarity is tied to specific groups (Hechter 1987; Hunt and Benford 2004; Scholz 2008) and thus conditional on the assumed social proximity, neediness, or deservingness of the targeted recipients (van Oorschot 2006). For this reason, it is not enough to measure a 
general disposition to help others. More than that, it is essential to list various potential target groups. In spatial terms, it is necessary to differentiate between solidarity with people within the respondents' countries, with other people within the European Union, and beyond Europe. Moreover, it is important to assess whether citizens make a difference when dissimilar target groups are addressed, such as refugees/asylum seekers, the unemployed, and the disabled.

The conceptual clarifications presented so far guided the design of our survey and allowed us to assemble a comprehensive comparative dataset. Our data enables us to describe levels of solidarity dispositions and activities within the eight countries under study and give a nuanced and differentiated picture of various forms of (target-specific) solidarity. Among other things, we are able to contextualize European solidarity and compare it with other (group-bound) forms of solidarity. This descriptive aim, however, was not the only objective of this survey. More than that, TransSOL was geared to shed light on those factors that are beneficial or detrimental for solidarity at large, and European solidarity in particular. Building on previous research, as indicated below, we know that solidarity among citizens is highly patterned by a battery of factors, namely, sociodemographic traits, social class, political allegiances, social capital, religious beliefs, and values among others; we included these variables in our study. In order to systematize this evidence, we propose to distinguish between three strands of inquiry.

A first source of inspiration comes from empirical research about redistributive preferences. These studies are interested in identifying those factors that guarantee the support of citizens for the welfare state at large, and various social policies in particular, and thus spur the backing of institutionalized forms of wealth redistribution and help (Alesina and Giuliano 2011; Amat and Wibbels 2009; Fong 2001; Rehm 2009; Rehm et al. 2012; Svallfors 1997). Studies have addressed a variety of social policy fields, among them pensions (Jaime-Castillo 2013), poverty (Alesina and Glaeser 2004; Scheepers and Grotenhuis 2005), and immigration (Banting and Kymlicka 2006; Mau and Burkhardt 2009). Evidence suggests that the support for redistributive preferences is influenced by the respondents' position in society, for example, the 'rational calculations' tied to their state of vulnerability (Iversen and Soskice 2001; Rehm 2009). Additionally, cognitive and ideational factor also play a role. Research has pointed to the role of religion and religiosity (Stegmueller et al. 2012; Lichterman 2015) and political socialization (Grasso et al. 2017a), but also general beliefs 
about the causes of income inequality (Fong 2001) and perceptions of deservingness (van Oorschot 2006) are important factors, too. In regard to the latter, research has identified several criteria that influence the judgment of deservingness: (1) the level of perceived responsibility and neediness, (2) social and spatial proximity and identity, including loyalties to ethnic groups, and (3) the recipients' attitudes and the degree of reciprocation (receiving and giving) (van Oorschot 2000, 2006; Alesina and Glaeser 2004; Luttmer 2001).

Second, the extensive field of studies on social capital and social cohesion is relevant for our discussion here, as well. In part, this research strand measures a similar phenomenon, as it is interested in forms of voluntary engagement within civic groups and organizations (Putnam et al. 2003; van Oorschot et al. 2006). However, social capital is not identical with solidarity, because social capital refers to those resources or ingredients that need to be mobilized into acts of solidarity. In this sense, this research strand provides helpful indications for our explanatory purposes, as it is interested in the conditions of interpersonal help and support. Here, in particular, it highlights the importance of interpersonal and institutional trust, of norms of reciprocity, and of informal networks as necessary ingredients of social cohesion (Chan et al. 2006; Jeannotte 2000; Delhey 2007) and thus as determining factors that help in explaining interpersonal solidarity. Moreover, studies of social cohesion have corroborated the importance of social class, age, and gender. They have shown that post-materialist values and religious beliefs play a beneficial role, whereas societies with social cleavages, political conflicts, and less developed welfare state institutions provide a less conducive environment (Kumlin and Rothstein 2005; van Oorschot and Arts 2005; Gelissen et al. 2012).

Finally, there are also lessons to be drawn from research on political behavior, in general, and social movement and protest participation, more specifically. These strands of research focus on the political dimensions of solidarity, and thus help to answer the question of whether political solidarity is determined by similar factors as the ones discussed above. Scholarly writing seems to support some of the research assumptions presented before, by showing how political behavior is patterned by social inequalities and forms of social exclusion (Brady et al. 1995; Kronauer 1998; Grasso 2013; Dunn et al. 2014; Giugni and Grasso 2015a; Grasso et al. $2017 b$ ). Moreover, studies agree on the fact that solidarity is also highly patterned by political preferences and orientation, for example, along the left-right scale (Likki and Staerklé 2014). Social movement analysis adds 
relevant knowledge by pointing to the importance of mobilization processes lead by existing organizations and groups, with the latter considered as collective means of mobilizing, organizing, and perpetuating (transnational) solidarity in terms of binding norms, commitments, and behaviors (Smith 1997; Balme and Chabanet 2008; della Porta and Caiani 2011; Baglioni and Giugni 2014; Giugni and Grasso 2015b). That is, being a member or follower of a certain initiative, association, organization, or movement implies a commitment not only to specific norms of solidarity but also to palpable acts as well (e.g., membership fees and charitable donations, joint political protests, events of claims-making).

Based on these insights, the survey included a series of questions that geared to gather data on all these explanatory factors. This information should allow us to identify those variables that tend to boost or inhibit solidarity dispositions and practices along the various dimensions identified before. In particular, it will enable us to ascertain whether European solidarity is inhibited or promoted by the same factors as solidarity with other reference groups. First, we are interested to see whether sociodemographic characteristics like age, gender, and race make a difference in regard to solidarity activities and dispositions. The study of civil societies, for instance, has shown that voluntary engagement tends to replicate the public/private divide by centering more strictly on male-dominated and 'public' activities, to the detriment of female networks of care and help (Neill and Gidengil 2006; Valentova 2016). It has been shown that younger and older citizens are more active in social movements, following different grades of 'biographical availability' in the life course (Beyerlein and Bergstrand 2013). And we know that migrants are often involved in cross-national networks of support and help (Glick Schiller et al. 1995; Morokvasic 1999; Recchi and Favell 2009). Second, we wish to test whether solidarity is patterned by the differential access of citizens to valued resources and skills, such as income and education, by the respondents' social status and affiliation to social class (Verba et al. 1978; Cainzos and Voces 2010) and by different levels of social exclusion and deprivation (Kronauer 1998). Third, we wish to analyze to what extent solidarity is conditioned by social capital, following the propositions of research devoted to civil society and social movements (Putnam et al. 2003; van Oorschot et al. 2006; Jenkins 1983). In particular, we wish to highlight the role of institutional and interpersonal trust, of informal networks and social relations, and of associational involvement in a wide range of social, cultural, and political organizations and groups. Fourth, we aim to identify 
the interrelation between political orientations and behaviors on the one side, and solidarity dispositions and practices on the other. In particular, we try to assess whether relevant factors investigated at the national level, for example, levels of political participation, political preferences, and ideological orientations (e.g., Blekesaune and Quadagno 2003; Amat and Wibbels 2009; Likki and Staerklé 2014; Giugni and Grasso 2017), also differentiate citizens with regard to solidarity. Finally, we wanted to identify the role of ideational and cognitive factors, too, assuming that the collective identities and the attachment to groups and communities might condition levels of solidarity (Luttmer 2001; Komter 2005) as much as religion and religiosity (Stegmueller et al. 2012; Lichterman 2015), moral norms, and visions of a desirable social order (Stets and McCaffree 2014).

\section{Structure And ObJectives of the Book}

This book is based on data gathered by a comparative research project and aims to answer a number of questions related to solidarity. How developed are solidarity attitudes and practices among citizens of European member states? How diffused are these orientations when comparing various target groups, among them refugees/migrants, unemployed people, and the disabled? And how strongly are citizens engaged in helping people outside their country, both within and outside Europe? Which groups in the European citizenry are strongest supporters of European solidarity, and which segments exhibit distance from European or global solidarity? Available studies have shown that the idea of solidarity across borders is supported by a considerable proportion of the European citizenry, suggesting that the long history of European integration has had an impact on the ideas and preferences of the population (Lengfeld et al. 2015; de Vries and Hoffmann 2016). However, this evidence is far from painting a comprehensive picture. Moreover, most studies have focused on the support of public policies of redistribution and burden sharing, to the detriment of studies about civic and interpersonal forms of solidarity.

The survey data presented in this book provides fresh insights into this topic. It is based on an online individual survey conducted in the winter months of 2016/2017 in Denmark, France, Germany, Greece, Italy, Poland, Switzerland, and the United Kingdom. The same questionnaire was administered in the relevant languages to approximately 2000 respondents in each of the countries of the project, thus assembling data on more than 16,000 European citizens. Respondent samples were matched to 
national statistics with quotas for education, age, gender, and region, and population weights are applied in the analyses presented in this volume. The questionnaire was drafted to measure solidarity in its various dimensions and manifestations, as indicated before, and to assemble data on a number of potential factors that might help to explain this practiced solidarity.

The chapters included in this volume aim to answer the above stated questions in regard to each of the eight countries under study. They are committed to three overall objectives. First, national chapters engage in a descriptive account of levels and forms of solidarity practices in each of the eight countries. The dependent variables consist of reported solidarity practices, such as donating time or money, buying or boycotting products, protest participation, or passive and active associational membership. Depending on the national contextual relevance, the chapters also compare levels of solidarity in regard to various reference groups: for example, solidarity with people from the own country, from other European country, or countries outside Europe; solidarity with disabled people, the unemployed, and refugees/migrants. These findings enable the portrayal of countryspecific levels of reported solidarity practices. Second, national chapters analyze the forces that affect practiced solidarity and in portraying the social profile of the most and least solidarity-prone groups of the population. For this purpose, the national chapters engaged with analyzing the explanatory relevance of the different factors introduced in this chapter. On the one hand, chapters focus on the social traits of the respondents, arguing that their position in the social structure impinges on the means and opportunities they have to commit themselves to solidarity. On the other hand, we assume that reported solidarity is conditioned also by attitudinal dispositions and preferences, such as political attitudes, social beliefs, or cultural values. Finally, each chapter explores specific aspects that seem particularly important either for the country under analysis and/or in view of research debates and questions awaiting empirical validation.

The book ends with a concluding chapter that wishes to paint a comparative picture of civic solidarity within and across European member states. For these purposes, we describe the main findings from our survey in comparative terms by presenting and highlighting the various levels of solidarity-driven practices and attitudes, and by identifying the importance of European solidarity, when compared to national or global solidarities in Europe. Moreover, knowledge assembled by the various national chapters will help us to assess whether solidarity-and European 
solidarity in particular-is driven by similar or different forces in the various countries under analysis. In this way, this volume provides a unique resource for understanding solidarity in contemporary Europe.

\section{REFERENCES}

Alesina, A., \& Giuliano, P. (2011). Preferences for Redistribution. In J. Benhabibi, A. Bisin, \& M. Jackson (Eds.), Handbook of Social Economics. San Diego: North-Holland.

Alesina, A., \& Glaeser, E. (2004). Fighting Poverty in the US and Europe: A World of Difference. Oxford: Oxford University Press.

Amat, F., \& Wibbels, E. (2009). Electoral Incentives, Group Identity and Preferences for Redistribution. Instituto Juan March de Estudios e Investigaciones Working Paper 246.

Baglioni, S., \& Giugni, M. (Eds.). (2014). Civil Society Organizations, Unemployment, and Precarity in Europe. Between Service and Policy. Houndmills, Basingstoke: Palgrave Macmillan.

Balibar, E. (2010). Europe: Final Crisis? Some Theses. Theory \& Event, 13(2). Project MUSE. https://doi.org/10.1353/tae.0.0127.

Balme, R., \& Chabanet, D. (2008). European Governance and Democracy. Power and Protest in the EU. Lanham, MD: Rowman and Littlefield.

Bandy, J., \& Smith, J. (2005). Factors Affecting Conflict and Cooperation in Transnational Movement Networks. In J. Bandy \& J. Smith (Eds.), Coalitions Across Borders. Transnational Protest and the Neoliberal Order (pp. 231-252). Lanham: Rowman \& Littlefield.

Banting, K. G., \& Kymlicka, W. (Eds.). (2006). Multiculturalism and the Welfare State: Recognition and Redistribution in Contemporary Democracies. Oxford: Oxford University Press.

Beck, U., \& Grande, E. (2007). Cosmopolitan Europe (C. Cronin, Trans.). Cambridge: Polity Press.

Beyerlein, K., \& Bergstrand, K. (2013). Biographical Availability. In D. A. Snow, D. della Porta, B. Klandermans, \& D. McAdam (Eds.), The Wiley-Blackwell Encyclopedia of Social and Political Movements (pp. 137-138). New York: Wiley-Blackwell.

Blekesaune, M., \& Quadagno, J. (2003). Public Attitudes Toward Welfare State Policies: A Comparative Analysis of 24 Countries. European Sociological Review, $19(5), 415-427$.

Brady, H. E., Verba, S., \& Schlozman, K. L. (1995). Beyond SES: A Resource Model of Political Participation. The America Political Science Review, 89(2), 271-294.

Cainzos, M., \& Voces, C. (2010). Class Inequalities in Political Participation and the 'Death of Class' Debate. International Sociology, 25(3), 383-418. 
Chan, J., To, H., \& Chan, E. (2006). Reconsidering Social Cohesion: Developing a Definition and Analytical Framework for Empirical Research. Social Indicators Research, 75, 273-302.

Curtis, J. E., Baer, D. E., \& Grabb, E. G. (2001). Nations of Joiners: Explaining Voluntary Association Membership in Democratic Societies. American Sociological Review, 66(6), 783-805.

Delanty, G., \& Rumford, C. (2005). Rethinking Europe: Social Theory and the Implications of Europeanization. Abingdon and New York: Routledge.

Delhey, J. (2007). Do Enlargements Make the European Union Less Cohesive? An Analysis of Trust Between EU Nationalities. Journal of Common Market Studies, 45(2), 253-279.

della Porta, D., \& Caiani, M. (2011). Social Movements and Europeanization. Oxford: Oxford University Press.

Dunn, A., Grasso, M. T., \& Saunders, C. (2014). Unemployment and Attitudes to Work: Asking the 'Right' Question. Work, Employment, and Society, 28(6), 904-925.

Durkheim, E. (1893/1997). The Division of Labor in Society. New York: Free Press.

Eurobarometer. (2011, September). Eurobarometer 76.1: Financial and Economic Crisis, Financial Services, Corruption, Development Aid, and Gender Equality. Brussels: EU-Commission (ICPSR 34552).

Fong, C. (2001). Social Preferences, Self-Interest, and the Demand for Redistribution. Journal of Public Economics, 82(2), 225-246.

Gelissen, J., Wim, J. H., van Oorschot, W., \& Finsveen, E. (2012). How Does the Welfare State Influence Individuals' Social Capital? Eurobarometer Evidence on Individuals' Access to Informal Help. European Societies, 2012, 1-25.

Giugni, M., \& Grasso, M. (Eds.). (2015a). Austerity and Protest: Popular Contention in Times of Economic Crisis. London: Routledge.

Giugni, M., \& Grasso, M. T. (2015b). Environmental Movements in Advanced Industrial Democracies: Heterogeneity, Transformation, and Institutionalization. Annual Review of Environment and Resources, 40, 337-361.

Giugni, M., \& Grasso, M. T. (2017). Blame and Contention: How Perceptions of the Government's Role in the Economic Crisis Shape Patterns of Political Action. Acta Politica (Open Access). Retrieved from https://link.springer. com/article/10.1057\%2Fs41269-017-0073-x.

Giugni, M., \& Grasso, M. (Eds.). (2018). Citizens and the Crisis: Perceptions, Experiences, and Responses to the Great Recession in Europe, Palgrave Studies in European Political Sociology. London: Palgrave Macmillan.

Giugni, M., \& Passy, F. (Eds.). (2001). Political Altruism? Solidarity Movements in International Perspective. Lanham, MD: Rowman \& Littlefield.

Glick Schiller, N., Basch, L., \& Szanton-Blanc, C. (1995). From Immigrant to Transmigrant: Theorizing Transnational Migration. Anthropological Quarterly, $68(1), 48-63$. 
Grasso, M. T. (2011). Political Participation in Western Europe. D.Phil. Thesis, Nuffield College, University of Oxford.

Grasso, M. T. (2013). The Differential Impact of Education on Young People's Political Activism: Comparing Italy and the United Kingdom. Comparative Sociology, 12(1), 1-30.

Grasso, M. T. (2016). Generations, Political Participation and Social Change in Western Europe. London: Routledge.

Grasso, M. T., \& Giugni, M. (2016). Protest Participation and Economic Crisis: The Conditioning Role of Political Opportunities. European Journal of Political Research, 55(4), 663-680.

Grasso, M. T., Farrall, S., Gray, E., Hay, C., \& Jennings, W. (2017a). Thatcher's Children, Blair's Babies, Political Socialisation and Trickle-Down ValueChange: An Age, Period and Cohort Analysis. British Journal of Political Science. https://doi.org/10.1017/S0007123416000375.

Grasso, M. T., Yoxon, B., Karampampas, S., \& Temple, L. (2017b). Relative Deprivation and Inequalities in Social and Political Activism. Acta Politica (Open Access). Retrieved from https://link.springer.com/ article/10.1057\%2Fs41269-017-0072-y.

Habermas, J. (2017, March 16). Why the Necessary Cooperation Does Not Happen: Introduction to a Conversation Between Emmanuel Macron and Sigmar Gabriel on Europe's Future. Paper presented at the Hertie School of Governance in Berlin. Retrieved May 9, 2017, from https://www.socialeurope.eu/2017/03/ pulling-cart-mire-renewed-case-european-solidarity/.

Hechter, M. (1987). Principles of Group Solidarity. Berkeley: University of California Press.

Hunt, S. A., \& Benford, R. D. (2004). Collective Identity, Solidarity, and Commitment. In D. A. Snow, S. A. Soule, \& H. Kriesi (Eds.), The Blackwell Companion to Social Movements (pp. 433-457). Oxford: Blackwell.

Iversen, T., \& Soskice, D. (2001). An Asset Theory of Social Policy Preferences. American Political Science Review, 95(4), 875-893.

Jaime-Castillo, A. M. (2013). Public Opinion and the Reform of the Pension Systems in Europe: The Influence of Solidarity Principles. Journal of European Social Policy, 23(4), 390-405.

Jeannotte, M. S. (2000). Social Cohesion Around the World: An International Comparison of Definitions and Issues. Paper SRA-390.

Jenkins, J. C. (1983). Resource Mobilization Theory and the Study of Social Movements. Annual Review of Sociology, 9, 527-553.

Komter, A. E. (2005). Social Solidarity and the Gift. Cambridge: Cambridge University Press.

Kronauer, M. (1998). 'Social Exclusion' and 'Underclass': New Concepts for the Analysis of Poverty. In A. Hans-Jürgen (Ed.), Empirical Poverty Research in a Comparative Perspective (pp. 51-75). Aldershot: Ashgate. 
Kumlin, S., \& Rothstein, B. (2005). Making and Breaking Social Capital: The Impact of Welfare-State Institutions. Comparative Political Studies, 38(4), 339-365.

Lahusen, C. (2013). European Integration, Social Cohesion and Political Contentiousness. In B. Andreosso-O'Callaghan \& F. Royall (Eds.), Economic and Political Change in Asia and Europe. Social Movement Analyzes (pp. 31-52). Dordrecht: Springer.

Lengfeld, H., Schmidt, S., \& Häuberer, J. (2012). Solidarität in der europäischen Fiskalkrise: Sind die EU-Bürger zu finanzieller Unterstützung von hoch verschuldeten EU-Ländern bereit? Erste Ergebnisse aus einer Umfrage in Dentschland und Portugal. Hamburg Reports on Contemporary Societies No.5/2012, University of Hamburg.

Lengfeld, H., Schmidt, S., \& Häuberer, J. (2015). Is There a European Solidarity? Attitudes Towards Fiscal Assistance for Debt-Ridden European Union Member States. Report of the Department of Sociology No. 67, Leipzig.

Lichterman, P. (2015). Religion and Social Solidarity. A Pragmatist Approach. In L. Hustinx, J. von Essen, J. Haers, \& S. Mels (Eds.), Religion and Volunteering. Complex, Contested and Ambiguous Relationships (pp. 241-261). Cham: Springer.

Likki, T., \& Staerklé, C. (2014). A Typology of Ideological Attitudes Towards Social Solidarity and Social Control. Journal of Community and Applied Social Psychology, 24, 406-421.

Luttmer, B. (2001). Group Loyalty and the Taste for Redistribution. Journal of Political Economy, 109(3), 500-528.

Markovsky, B., \& Lawler, E. J. (1994). A New Theory of Group Solidarity. In B. Markovsky, K. Heimer, \& J. O'Brien (Eds.), Advances in Group Processes (pp. 113-137). Greenwich, CT: JAI Press.

Marshall, T. H. (1950). Citizenship and Social Class: And Other Essays. Cambridge: Cambridge University Press.

Mau, S., \& Burkhardt, C. (2009). Migration and Welfare State Solidarity in Western Europe. Journal of European Social Policy, 19(3), 213-229.

Morokvasic, M. (1999). La mobilité transnationale comme ressource: le cas des migrants de l'Europe de l'Est. Cultures et Conflits, 32, 105-122.

Neill, B., \& Gidengil, E. (Eds.). (2006). Gender and Social Capital. New York: Routledge.

van Oorschot, W. (2000). Who Should Get What, and Why? On Deservingness Criteria and the Conditionality of Solidarity Among the Public. Policy \& Politics, 28(1), 33-48.

van Oorschot, W. (2006). Making the Difference in Social Europe: Deservingness Perceptions Among Citizens of European Welfare States. Journal of European Social Policy, 16(1), 23-42. 
van Oorschot, W., \& Arts, W. (2005). The Social Capital of European Welfare States: The Crowding Out Hypothesis Revisited. Journal of European Social Policy, 15(1), 5-26.

van Oorschot, W., Arts, W., \& Gelissen, J. (2006). Social Capital in Europe. Measurement and Social and Regional Distribution of a Multifaceted Phenomenon. Acta Sociologica, XLIX, 149-167.

Parsons, T. (1966). Societies: Evolutionary and Comparative Perspectives. Englewood Cliffs, NJ: Prentice-Hall.

Putnam, R., Feldstein, L. M., \& Cohen, D. (2003). Better Together: Restoring the American Community. New York: Simon \& Schuster.

Recchi, E., \& Favell, A. (2009). Pioneers of European Integration. Citizenship and Mobility in the EU. Cheltenham: Edward Elgar.

Rehm, P. (2009). Risks and Redistribution. An Individual-Level Analysis. Comparative Political Studies, 42(7), 885-881.

Rehm, P., Hacker, J. S., \& Schlesinger, M. (2012). Insecure Alliances: Risk, Inequality and Support for the Welfare State. American Political Science Review, 106(2), 386-406.

Scheepers, P., \& Grotenhuis, M. T. (2005). Who Cares for the Poor in Europe? Micro and Macro Determinants for Alleviating Poverty in 15 European Countries. European Sociological Review, 21(5), 453-465.

Scholz, S. J. (2008). Political Solidarity. Penn State University Press.

Smith, J. (1997). Transnational Social Movements and Global Politics: Solidarity Beyond the State. Syracuse University Press.

Stegmueller, D., Scheepers, P., Roßteuscher, S., \& de Jong, E. (2012). Support for Redistribution in Western Europe. Assessing the Role of Religion. European Sociological Review, 28(4), 482-497.

Stets, J. E., \& McCaffree, K. (2014). Linking Morality, Altruism, and Social Solidarity Using Identity Theory. In V. Jeffries (Ed.), The Palgrave Handbook of Altruism, Morality, and Social Solidarity (pp. 333-351). New York: Palgrave Macmillan.

Stjerno, S. (2012). Solidarity in Europe. The History of an Idea. Cambridge: Cambridge University Press.

Svallfors, S. (1997). Worlds of Welfare and Attitudes to Redistribution: A Comparison of Eight Western Nations. European Journal of Sociology, 13(3), 283-304.

Valentova, M. (2016). How Do Traditional Gender Roles Relate to Social Cohesion? Focus on Differences Between Women and Men. Social Indicators Research, 127(1), 153-178.

Verba, S., Nie, N., \& Kim, J. (1978). Participation and Political Equality: A Seven Nation Comparison. London: Cambridge University Press. 
de Vries, C., \& Hoffmann, I. (2016). Border Protection and Freedom of Movement. What People Expect of European Asylum and Migration Policies. Gütersloh: Bertelsmann Stiftung euopinion 2016/1. Retrieved October 16, 2017, from https://www.bertelsmann-stiftung.de/en/publications/publication/did/ border-protection-and-freedom-of-movement/.

Open Access This chapter is licensed under the terms of the Creative Commons Attribution 4.0 International License (http://creativecommons.org/licenses/ by $/ 4.0 /)$, which permits use, sharing, adaptation, distribution and reproduction in any medium or format, as long as you give appropriate credit to the original author(s) and the source, provide a link to the Creative Commons license and indicate if changes were made.

The images or other third party material in this chapter are included in the chapter's Creative Commons license, unless indicated otherwise in a credit line to the material. If material is not included in the chapter's Creative Commons license and your intended use is not permitted by statutory regulation or exceeds the permitted use, you will need to obtain permission directly from the copyright holder.

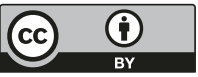

